\title{
Screening of HIV, HCV, HBV and Malaria among Migrants from Africa (Short communication)
}

K. Zoller (Katarina Zoller)', V. Krcmery (Vladimir Krcmery)'1, J. Polonova (Jaroslava Polonova)', T. Hrindova (Tatiana Hrindova)1, S. Hinze (Susana Hinze)', D. Dorko (Dominik Dorko)', B. Durecova (Barbora Durecova)', I. Bartosovic (Ivan Bartosovic)', 5. Spanik (Stanislav Spanik), N. Bujdova (Natasa Bujdova)', J. Ridosko (Jaroslav Ridosko)², P. A. Haji (Peri Ali Haji)'1

${ }^{1}$ St. Elisabeth Refugees and migrants centers, Catania Italy and Alexandria Greece

${ }^{2}$ University Hospital Trencin, Slovakia

\section{E-mail address:}

tropicteam@gmail.com

\section{Reprint address:}

Katarina Zoller

St. Elisabeth university refugee health $\mathrm{MSc} / \mathrm{PhD}$ programme UNHCR Refugee Camp Veria

Alexandria, Greece

Suource: Clinical Social Work and Health Intervention

Volume: 8

Issue: 3

Pages: $18-20$

Cited references: 8

\section{Reviewers:}

Steve Szydlowski

University of Scranton School of Education, USA

Victor Namulanda Wanjala

Catholic University of Eastern Africa, Nairobi, Kenya

\section{Key words:}

Refugee crisis, Migrants, ID, HIV, HBV, Malaria.

\section{Publisher:}

International Society of Applied Preventive Medicine i-gap

CSWHI 2017; 8(3): 18 - 20; DOI 10.22359/cswhi_8_3_03 @ 2017 Clinical Social Work and Health Intervention

\section{Abstract:}


EU via Greece. Occurrence of all screened diseases (HCV, HBV, HIV and malaria) was significantly higher among African migrants in comparison to those who were staying in camps or migrated via the Balkan route.

\section{Conflict of interest:}

The authors whose names are listed in the title of the article certify that they have NO affiliations with or involvement in any organization or entity with any financial interest (such as honoraria; educational grants; participation in speakers' bureaus; membership, employment, consultancies, or other equity interest), or non-financial interest (such as personal or professional relationships, affiliations, knowledge or beliefs) in the subject matter or materials discussed in this manuscript.

\section{Background}

Two major waves of refugees entered Europe in 2015; first via Greece and Turkey. The second wave entered Europe via Sicily and Malta using maritime transport. There were many papers published on differences between these two groups as far as communicable diseases are concerned. Diseases, such as malaria and other parasitic diseases were more prevalent in the group entering Malta and Sicily, probably due to the different origin of the migrants. The aim of this short paper was to compare results of the rapid tests for $\mathrm{HIV}, \mathrm{HBV}, \mathrm{HCV}$ and malaria in the groups of migrants of different origin using different points of entry to Europe.

\section{Methods}

Comparison of the results of screening tests for HBV, HIV and $\mathrm{HCV}$ was performed in two groups of migrants. The first group consisted of 199 migrants from Syria, Iraq and Afghanistan who stayed in the asylum and refugee camp in Veria, Greece. The second group consisted of prevalently African migrants (in total of 203), who were screened at refugee camp. Their main countries of origin were Somalia, Eritrea and Ethiopia.

\section{Results and discussion}

There was significant difference among two groups of migrants. Screening tests for malaria, HIV, HCV and HBV were significantly more often positive in the group of African migrants than in the migrants from the Middle East (0.5\% vs. 8.5\% HIV, 2.5\% vs. $9 \% \mathrm{HBV}, 0 \%$ vs. $5 \% \mathrm{HCV}, 0 \%$ vs. $35 \%$ for malaria, $\mathrm{p}>0.05$ ).

\section{Conclusions}

Refugees from the African continent are more likely to be hosts of HBV, HCV, HIV and malaria. Screening strategies should be therefore considered for various populations.

\section{References}

1. HAJJ PA et al (2016) Are migrants from Middle East carriers of multi-resistant bacteria? Clinical Social Work and Health Intervention Vol. 7 No. 320162.

2. PRESTILEO T, DI LORENZO F, CORRAO S (2015) Infectious Diseases among African irregular migrants in Italy. Just an individual problem? Clin. Soc. Work 2015, 5, 45.

3. TROVATO A, REID A, TAKARINDA KC, MONTALDO C, DECROO T, OWITI P, ... CARLO SD (2016) Dangerous crossing: 
demographic and clinical features of rescued sea migrants seen in 2014 at an outpatient clinic at Augusta Harbor, Italy. Conflict and Health, 10(1). doi:10.1186/ s13031-016-0080-y.

4. KIMULI D,CZARNECKI P, MIKLOSKOVA M, SPANIK S, BRYNDZAK $P$ et al (2016) Social pathology II. WMU WARSAW. 2016. 455 pp.

5. MANZARDO C, TREVIGNO B, GOMEZ I PRAT J, CABEZOS J et al. (2008) Communicable diseases in the immigrant population attended to in a tropical medicine unit: Epidemiological aspects and public health issue. Travel Medicine and Infectious Disease, 2008 Vol. 6, Issue 1, Pages 4-11. 2.
6. BREZINOVA M (2015) Assessment of functional potential in patients after amputation of the lower limbs. In: Rehabilitácia ISSN 0375-0922, Vol. 52, 2015, No 4, p. 218-226.

7. RIDOSKO J (2014) Treatment of intra-articular femur fractures. Radix, spol. s. r. o. ISBN 978-80-87573-09-9.

8. PRESTILEO T, CASSARA G, DI LORENZO F, SANFILIPPO A, DALLE NOGARE ER, ORLANDO G (2011) Infectious diseases and health in the migrant people: experience from Lampedusa 2011. Infezioni in Medicina: 2013. 17-24 - Vol. 21.

Table 1: Comparison of the refugee screening

\begin{tabular}{|l|l|l|}
\hline & African Migrants (Italy) & Middle East Migrants (Greece) \\
\hline HIV & $17 / 203(8.5 \%)$ & $1 / 199(0.5 \%)$ \\
\hline HBV & $18 / 203(9 \%)$ & $5 / 199(2.5 \%)$ \\
\hline HCV & $10 / 203(5 \%)$ & $0 / 199$ \\
\hline malaria & $9 / 203(3,5 \%)$ & $0 / 199$ \\
\hline
\end{tabular}

